\title{
Neuroprotection and acidosis induced by cortical spreading depression
}

\author{
This article was published in the following Dove Press journal: \\ Neuropsychiatric Disease and Treatment \\ 12 December 2016 \\ Number of times this article has been viewed
}

\section{Kenneth K Kwong \\ Suk-tak Chan}

Department of Radiology, MGH/MIT/ HMS Athinoula A. Martinos Center for Biomedical Imaging, Massachusetts General Hospital, Boston, MA, USA
Correspondence: Kenneth K Kwong Athinoula A. Martinos Center for Biomedical Imaging, Building I49, I3th Street, Mail Code 149-230I, Charlestown, MA 02129, USA Email kwong@nmr.mgh.harvard.edu

\section{Dear editor}

We read with interest the article "Cortical spreading depression produces a neuroprotective effect activating mitochondrial uncoupling protein-5" published in Neuropsychiatr Dis Treat by Viggiano et al. ${ }^{1}$ The authors showed that cerebral spreading depression (CSD) triggered uncoupling protein-5 (UCP-5), ${ }^{1}$ which had been reported to exert a long-term effect upon neuron protection. ${ }^{2}$ The result is another piece in CSD literature on modifying gene expressions to provide neuroprotection to subsequent ischemic episodes. ${ }^{3,4}$

An unmentioned but additional factor for neuroprotection in CSD could be acidosis.

Acidosis is a known consequence of CSD. ${ }^{5}$ In the literature, brief acidosis in ischemic conditions when oxygen supply is low has been shown to be cytoprotective and neuroprotective, ${ }^{6-10}$ a result related sometimes to the concept of the " $\mathrm{pH}$ paradox." ${ }^{9,11,12}$ Acidosis had been reported to reduce stroke infarct size with $\mathrm{CO}_{2}$ applied for a short time after reperfusion ${ }^{6}$ as well as during ischemic stroke. ${ }^{10}$ Brief acidosis applied after birth asphyxia ${ }^{7}$ was reported to successfully suppress brain alkalosis, which led to seizures. Hence, brief and relatively mild acidosis induced under the condition of CSD may be one of the neuroprotective factors for CSD. The role of acidosis in neuroprotection by CSD warrants further investigation.

Interestingly, CSD-induced acidosis could be one explanation of impaired cerebral vascular reactivity ${ }^{13-16}$ after CSD. It has been reported that once tissue reaches a certain low $\mathrm{pH}$ threshold, blood flow increase would be insignificant in response to even stronger $\mathrm{CO}_{2}$ challenge. ${ }^{10}$

\section{Disclosure}

The authors report no conflicts of interest in this communication.

\section{References}

1. Viggiano E, Monda V, Messina A, et al. Cortical spreading depression produces a neuroprotective effect activating mitochondrial uncoupling protein-5. Neuropsychiatr Dis Treat. 2016;12:1705-1710.

2. Nakase T, Yoshida Y, Nagata K. Amplified expression of uncoupling proteins in human brain ischemic lesions. Neuropathology. 2007;27(5):442-447.

3. Passaro D, Rana G, Piscopo M, Viggiano E, De Luca B, Fucci L. Epigenetic chromatin modifications in the cortical spreading depression. Brain Res. 2010;1329:1-9.

4. Taga K, Patel PM, Drummond JC, Cole DJ, Kelly PJ. Transient neuronal depolarization induces tolerance to subsequent forebrain ischemia in rats. Anesthesiology. 1997;87(4):918-925.

5. Mutch WA, Hansen AJ. Extracellular $\mathrm{pH}$ changes during spreading depression and cerebral ischemia: mechanisms of brain pH regulation. J Cereb Blood Flow Metab. 1984;4(1):17-27. 
6. Fan YY, Shen Z, He P, et al. A novel neuroprotective strategy for ischemic stroke: transient mild acidosis treatment by $\mathrm{CO} 2$ inhalation at reperfusion. J Cereb Blood Flow Metab. 2014;34(2):275-283.

7. Helmy MM, Tolner EA, Vanhatalo S, Voipio J, Kaila K. Brain alkalosis causes birth asphyxia seizures, suggesting therapeutic strategy. Ann Neurol. 2011;69(3):493-500.

8. Khacho M, Tarabay M, Patten D, et al. Acidosis overrides oxygen deprivation to maintain mitochondrial function and cell survival. Nat Commun. 2014;5:3550.

9. Laffey JG. Protective effects of acidosis. Anaesthesia. 2001;56(10): 1013-1014.

10. Simon RP, Niro M, Gwinn R. Brain acidosis induced by hypercarbic ventilation attenuates focal ischemic injury. J Pharmacol Exp Ther. 1993;267(3):1428-1431.

11. Laffey JG, Kavanagh BP. Carbon dioxide and the critically ill - too little of a good thing? Lancet. 1999;354(9186):1283-1286.
12. Swenson ER. Therapeutic hypercapnic acidosis: pushing the envelope. Am J Respir Crit Care Med. 2004;169(1):8-9.

13. Lauritzen M. Long-lasting reduction of cortical blood flow of the brain after spreading depression with preserved autoregulation and impaired CO2 response. J Cereb Blood Flow Metab. 1984;4(4):546-554.

14. Wahl M, Lauritzen M, Schilling L. Change of cerebrovascular reactivity after cortical spreading depression in cats and rats. Brain Res. 1987; 411(1):72-80.

15. Scheckenbach KE, Dreier JP, Dirnagl U, Lindauer U. Impaired cerebrovascular reactivity after cortical spreading depression in rats: restoration by nitric oxide or cGMP. Exp Neurol. 2006;202(2):449-455.

16. Guiou M, Sheth S, Nemoto M, et al. Cortical spreading depression produces long-term disruption of activity-related changes in cerebral blood volume and neurovascular coupling. J Biomed Opt. 2005;10(1): 11004. 


\section{Authors' reply \\ Giovanni Messina ${ }^{1,2}$ \\ Emanuela Viggiano ${ }^{1,3}$ \\ Vincenzo Monda' \\ Antonietta Messina' \\ Fiorenzo Moscatelli² \\ Anna Valenzano ${ }^{2}$ \\ Domenico Tafuri ${ }^{4}$ \\ Vincenzo De Luca ${ }^{5}$ \\ Giuseppe Cibelli² \\ Marcellino Monda'}

'Section of Human Physiology and Unit of Dietetic and Sport Medicine, Department of Experimental Medicine, Second University of Naples, Caserta, ${ }^{2}$ Department of Clinical and Experimental Medicine, University of Foggia, Foggia, ${ }^{3}$ Department of Medicine, University of Padua, Padua, ${ }^{4}$ Department of Motor Sciences and Wellness, University of Naples "Parthenope," Napoli, Italy; ${ }^{5}$ Department of Psychiatry, University of Toronto, Toronto, ON, Canada

Correspondence: Giovanni Messina

Department of Clinical and Experimental Medicine,

University of Foggia, Via L Pinto, 7I I 22 Foggia, Italy

Tel +398I 5665804

$\mathrm{Fax}+39815665844$

Email gianni.messina@unina2.it

\section{Dear editor}

Thank you for the attention paid to our article entitled: "Cortical spreading depression produces a neuroprotective effect activating mitochondrial uncoupling protein -5 ". ${ }^{1}$ We do agree that cerebral spreading depression (CSD)-induced acidosis is an intriguing aspect of the neuroprotection puzzle. It is well known that CSD is involved in the pathophysiology of migraine, cerebral ischemia, subarachnoid hemorrhage, and traumatic brain injury. ${ }^{2-7}$ Moreover, it is also involved in traumatic and spontaneous intracerebral hemorrhage, as well as in migraine aura and epilepsy. ${ }^{8-10}$ The induction of CSD during ischemia causes an increase in tissue damage, while preconditioning with CSD decreases the damage induced by a subsequent episode of ischemia. ${ }^{11}$ Anyway, the mechanisms underlying these effects, as well as the neuroprotection induced by CSD, remain unclear.

Our results are consistent with the hypothesis that CSD might induce its neuroprotective effect by means of uncoupling electron transport from ATP synthesis, mediated by the activation of the mitochondrial uncoupling proteins (UCPs). Such an idea is supported by the experimental evidence of the neuroprotective effect due to upregulation of UCPs in response to oxidative stress; in fact, reactive oxygen species seem to play a major role in the phenomenon of ischemia-reperfusion..$^{12}$ But, reperfusion itself induces also an important inflammatory response, characterized by a massive production of free radicals and by the activation of the complement and leukocytes. Therefore, the intracellular acidosis, the oxidative stress, the production of cytokines, and the secondary mitochondrial lesions may represent competing factors involved in the CSD-induced neuroprotection. ${ }^{11-15}$

Therefore, according to authors' letter, further studies are needed to prove this multifaceted reality.

\section{Disclosure}

The authors report no conflicts of interest in this communication.

\section{References}

1. Viggiano E, Monda V, Messina A, et al. Cortical spreading depression produces a neuroprotective effect activating mitochondrial uncoupling protein-5. Neuropsychiatr Dis Treat. 2016;12:1705-1710.

2. Kramer DR, Fujii T, Ohiorhenuan I, Liu CY. Cortical spreading depolarization: pathophysiology, implications, and future directions. J Clin Neurosci. 2016;24:22-27.

3. Bhaskar S, Saeidi K, Borhani P, Amiri H. Recent progress in migraine pathophysiology: role of cortical spreading depression and magnetic resonance imaging. Eur J Neurosci. 2013;38(11):3540-3551.

4. Dreier JP, Körner K, Ebert N, et al. Nitric oxide scavenging by hemoglobin or nitric oxide synthase inhibition by $\mathrm{N}$-nitro-L-arginine induces cortical spreading ischemia when $\mathrm{K}+$ is increased in the subarachnoid space. J Cereb Blood Flow Metab. 1998;18(9):978-990.

5. Gold L, Back T, Arnold G, et al. Cortical spreading depression-associated hyperemia in rats: involvement of serotonin. Brain Res. 1998;783(2): 188-193.

6. Hartings JA, Tortella FC, Rolli ML. AC electrocorticographic correlates of peri-infarct depolarizations during transient focal ischemia and reperfusion. J Cereb Blood Flow Metab. 2006;26(5):696-707.

7. Nilsson P, Gazelius B, Carlson H, Hillered L. Continuous measurement of changes in regional cerebral blood flow following cortical compression contusion trauma in the rat. J Neurotrauma. 1996;13(4): 201-207.

8. Eising E, Shyti R, 't Hoen PA, et al. Cortical spreading depression causes unique dysregulation of inflammatory pathways in a transgenic mouse model of migraine. Mol Neurobiol. 2016. Epub Mar 31, 2016.

9. Petrusic I, Zidverc-Trajkovic J. Cortical spreading depression: origins and paths as inferred from the sequence of events during migraine aura. Funct Neurol. 2014;29(3):207-212.

10. Yeom JS, Kim YS, Lee JH, Jung S, Kwon OY. Temporal current-source of spikes suggests initial treatment failure in childhood absence epilepsy. Seizure. 2015;31:88-93.

11. Viggiano A, Viggiano E, Valentino I, et al. Cortical spreading depression affects reactive oxygen species production. Brain Res. 2011;1368: $11-18$.

12. Kim-Han JS, Dugan LL. Mitochondrial uncoupling proteins in the central nervous system. Antioxid Redox Signal. 2005;7(9-10):1173-1181.

13. Betts J, Jaros E, Perry RH, et al. Molecular neuropathology of MELAS: level of heteroplasmy in individual neurones and evidence of extensive vascular involvement. Neuropathol Appl Neurobiol. 2006;32(4): 359-373.

14. Seitz I, Dirnagl U, Lindauer U. Impaired vascular reactivity of isolated rat middle cerebral artery after cortical spreading depression in vivo. J Cereb Blood Flow Metab. 2004;24(5):526-530.

15. Gourdin MJ, Bree B, De Kock M. The impact of ischaemia-reperfusion on the blood vessel. Eur J Anaesthesiol. 2009;26(7):537-547. 
Dove Medical Press encourages responsible, free and frank academic debate. The content of the Neuropsychiatric Disease and Treatment 'letters to the editor' section does not necessarily represent the views of Dove Medical Press, its officers, agents, employees, related entities or the Neuropsychiatric Disease and Treatment editors. While all reasonable steps have been taken to confirm the content of each letter, Dove Medical Press accepts no liability in respect of the content of any letter, nor is it responsible for the content and accuracy of any letter to the editor.

\section{Publish your work in this journal}

Neuropsychiatric Disease and Treatment is an international, peerreviewed journal of clinical therapeutics and pharmacology focusing on concise rapid reporting of clinical or pre-clinical studies on a range of neuropsychiatric and neurological disorders. This journal is indexed on PubMed Central, the 'PsycINFO' database and CAS, and is the official journal of The International Neuropsychiatric Association (INA). The manuscript management system is completely online and includes a very quick and fair peer-review system, which is all easy to use. Visit http://www.dovepress.com/testimonials.php to read real quotes from published authors.

Submit your manuscript here: http://www.dovepress.com/neuropsychiatric-disease-and-treatment-journal 